\title{
Moderating roles of customer characteristics on the link between service factors and satisfaction in a buffet restaurant
}

\begin{abstract}
Purpose:

In service sector, measuring quality of services is generally acknowledged to be difficult as it involves many psychological features. Hence, identifying the determinants of service quality and linkages with customer satisfaction is a challenging research topic. In this study, we take up a research study to address this challenge. Specifically, we examine the importance of factors influencing customer satisfaction in the context of a Chinese buffet restaurant in the UK.
\end{abstract}

\section{Design:}

We use a questionnaire based on the SERVQUAL instrument for the purpose. Using exploratory and confirmatory factor analyses, we have found that service quality could be grouped into four main factors - service, food, ambience and price.

\section{Findings:}

Using multiple regression analysis, we have found that food is the most significant factor influencing customer satisfaction, followed by price, ambience, and service respectively. Using a multi-group analysis, we have found interesting moderating roles of age, gender and annual income on the influence of the four factors on satisfaction: ambience is considered significant by male customers while it is not significant for female customers; the influence of price on satisfaction is much higher for female customers than for male customers; food and service factors are important for younger customers while price is important for older customers; price is important for customers with lower levels of income but not important for high-income customers.

\section{Practical implications:}

These results are useful to restaurant managers in allocating appropriate levels of resources to different factors based on their contributions to customer satisfaction in order to maximize customer satisfaction efficiently and effectively.

\section{Originality:}

Analysis and findings of this research are based on the customers' survey data of a Chinese buffet restaurant in the UK. We have found an interesting ranking of the importance of service factors: food followed by price, ambience, and service. Our results on the moderating role of customer characteristics provide newer insights in the literature on service quality. Our research findings can help the hotel management to improve their service levels to attain maximum customer satisfaction.

Keywords: customer satisfaction, service quality, buffet restaurant, SERVQUAL 


\section{Introduction}

Available data indicates that the service sector is growing faster than the manufacturing sector. The share of the service sector is larger in more developed economies (Fitzsimmons and Fitzsimmons, 2008). According to Wirtz et al. (2015) who used data from the World Bank and World Trade Organisation, the share of service sector in the World economy was over $70 \%$ and it was $73 \%$ in the developed economies. This sector is also set to grow further in the future. Hence, it is important to pay special attention to the characteristics of the service sector and also to the customers' feelings that distinguish it from traditional manufacturing (Lee, 2009). Services, compared to manufacturing, involve the conversion of resources into an "intangible" output (Adam and Swamidass, 1989). Service operations are distinguished by the following major characteristics: customer participation, simultaneity, perishability, intangibility and heterogeneity (Fitzsimmons and Fitzsimmons, 2008). Due to the closeness of the service business to customers, service operations must be extremely sensitive to customers and markets (Adam and Swamidass, 1989) and achieving customer satisfaction is a challenge in the service sector.

Due to the distinct characteristics of the service sector, measuring quality of services is generally acknowledged to be more difficult as it involves many psychological features (Fitzsimmons and Fitzsimmons, 2008). Hence, identifying the determinants of service quality and linkages with customer satisfaction is a challenging research topic. In this study, we take up a research study to address this challenge. Specifically, we examine the importance of factors influencing customer satisfaction in the context of a Chinese buffet restaurant in the UK.

The restaurant sector is one of the fastest and consistently growing service sectors in the UK. Turnover in the UK restaurant sector reached $£ 21.6$ bn in 2014, up from $£ 15.5$ bn in 2010, registering an impressive increase by 39\% during this period (Shubber, 2015) in spite of economic downturn. Customers in the UK on an average spend $27 \%$ of their weekly food budget on eating out in restaurants, which are the preferred meal destinations followed by pubs and fast-food outlets. Such a sharp growth of the restaurant sector can be attributed to a great extent to changing lifestyles and improving economic conditions in the UK. This level of growth has also increased competition in restaurants in attracting customers, and the importance of improving service quality has been recognized in the literature as vital for attracting customers (Robledo, 2001).

This study focuses on service quality in restaurants. Usually, perceived quality has been regarded as one of the most significant determinants of customer satisfaction in the service industry (Namkung and Jang, 2008). For the specific restaurant context, perceived quality can be further decomposed into sub-factors, for example, into food quality, service quality, ambience quality, price, etc. We explore the relationships of these factors in influencing customer satisfaction in this paper. More specifically, the objectives of this study are: (1) to identify important attributes influencing customer satisfaction in restaurants based on previous studies; (2) to evaluate customers' perceptions with respect to the performance of these attributes; (3) to check whether these attributes could be 
grouped into meaningful factors; (4) to prioritize those factors based on their influencing power on improving customer satisfaction; and (5) to identify the moderating influence of various customer characteristics on the influence of customer-service factors on satisfaction.

This paper is organized as follows. We review the related literature and develop hypotheses in the next section. We describe our research methodology in Section 3. Data analysis and results are presented in Section 4. Results of the analysis are further discussed in Section 5, where important managerial implications of the results are also discussed. Finally, we present our conclusions and research limitations in Section 6.

\section{Literature Review and hypothesis development}

\subsection{Service quality and measurement}

Service quality is usually based on the assessment of customers in relation to overall excellence or superiority of the service provided (Parasuraman et al., 1988). It is commonly recognized as a multi-dimensional construct. In spite of newer ways of measuring service quality for example using AHP and Topsis methods (e.g., Ramanathan and Karpuzcu, 2011; Yildiz and Yildiz, 2015), a majority of studies on service quality builds on the SERVQUAL instrument developed by Parasuraman et al. (1988) as it provides an interesting way of measuring the multiple dimensions of service quality. The SERVQUAL instrument is based on measuring expected service quality, measuring perceived service quality and identifying the difference between the two. The instrument has been applied in different service sectors (hotels, restaurants, airlines, etc.). However, more recent literature has used variations of this instrument. For example, there is a view that perception based parts are more important in the SERVQUAL instrument (Roses et al., 2009). Though the causal relationship between restaurants quality and customer satisfaction been accepted in theory, not many studies have verified this relationship in restaurant industry in a practical context (Lin et al., 2010; Cao and Kim, 2015). With the purpose of filling the gap, this study intends to examine the correlation between perceived restaurant quality and customer satisfaction. Further, though there is a general agreement that the relationship between service-factors and satisfaction could vary depending on specific characteristics of customers, there are relatively few studies that have empirically analysed this influence. We attempt to fill this gap as well.

\subsection{Attributes influencing customer satisfaction in restaurants}

Reuland et al (1985) claimed that the hospitality industry is a harmonious mixture combining three factors: the material product, the behaviour and attitude of service providers, and the environment. Berry et al (2002) also suggested that the service experience can be described from three categorized elements: technical quality of service, behaviour of employees, and elements in the service environment. With particular reference to the context of restaurants, Clark and Wood (1999) asserted that "meal experience" was a holistic abstraction of multiple factors (food, price and 
atmosphere) in consumers' mind. This view has been verified in subsequent studies (e.g,, Robledo, 2001), and the present study also takes a similar approach, dividing overall service quality of a restaurant into food, service, ambience, and price. The literature also calls for focusing on special attributes of special cases in evaluating overall service quality, and the present study contributes to this literature by focusing on special attributes of Chinese buffet restaurants.

\subsubsection{Food}

Food quality has been viewed as a major criterion for patrons to judge performance of restaurants. Soriano (2002) investigated an up-scale Spanish restaurant and indicated that respondents rated food quality as the most vital element of the restaurant. Johns and Pine (2002) felt that low price and high food quality, evaluated using food temperature, presentation, freshness and selection range, could be important factors for success of restaurants. Wansink (2005) has found that patrons regarded appearance of a dish as very important for their dining experience. Food safety has been regarded as a basic requirement by customers when measuring food quality (Sulek and Hensley, 2004). Healthy food is one of the qualities to measure food in restaurants. With a growing number of experienced patrons, attractiveness has become a vital criterion when consumers evaluate performance of restaurants (Kivela, 1997). As one component of attractiveness, some scholars suggested that new dining experiences should be provided by restaurants through offering unique dishes and revising cuisines regularly (Lin and Mattila, 2006).

Perceived food quality has been regarded as one of candidates that results in customer satisfaction in restaurant setting (Law et al., 2004; Johns and Howard, 1998). Accordingly, the relationship between food quality and customer satisfaction is posited as our first hypothesis:

H1. Food quality positively and significantly influences customer satisfaction in restaurants.

\subsubsection{Service}

Restaurants offer both food and service. Thus customers in a restaurant not only experience the taste of food but also experience service encounters during their meal. Pugh (2001) claimed that positive emotions by customers have positive effects on their perceptions of service quality. For instance, waiters should be able to provide prompt and convenient payment. If there are problems due to incorrect billing, long waiting time to pay and ignorance of servers, the entire dining experience could be ruined even if the meal itself was viewed as perfect by patrons (Pugh, 2001). In the context of a buffet restaurant, this positive emotion can also be experienced when dishes are replenished regularly and used plates are withdrawn promptly. Meanwhile, researchers have pointed out that honoring customers reservations correctly is a requirement criterion for patrons to perceive good service quality (Lee and Hing, 1995). Accessible location and convenient operating time are vital 
attributes considered by experienced customers when choosing restaurant (Soriano, 2002; Tzeng et al ., 2002)

Since customers participative in the entire service providing process in a restaurant, the ability of service personnel in communicating with consumers without difficulties is important for customers' perceptions of service quality. This is especially vital for Chinese restaurants. Law et al (2008) investigated the Mainland Chinese travellers' perceptions in terms of their dining experiences in Hong Kong restaurants. And the results showed that many respondents have unsatisfied meal experiences due to the difficulties in communicating with servers. Therefore, the servers' language proficiency is an essential attribute which has influence on customers' perceptions of restaurant's performance.

Wansink et al (2005) pointed out that consumers could generate some favorable comments for the labelled dishes. For instance, if cooking method of the dish is labelled in detail, patrons intend to think it is more appealing and tasty than other dishes without labelling. It is particularly important for specialty restaurants such as Chinese restaurants, since some patrons are unfamiliar with Chinese cuisines. If detailed information of dishes (such as calorie and nutrition level, involved ingredients, warning labels, cooking method) is offered inside of the restaurant or on its website, consumers could generate positive evaluations for the restaurant's service quality. The similar positive measurement could be obtained through clearly labelled signs in different buffet sections.

Thus, consistent with the converging proposition that a good quality customer service results in customer satisfaction, the second hypothesis in this study is that:

\section{H2. Quality of customer service positively and significantly influences customer satisfaction.}

\subsubsection{Ambience}

Substantial studies have agreed on the significance of environment attributes, and even implied them as one of the essential cues for patrons to judge performance of restaurants. For example, Rust and Oliver (1994) claimed that customers make judgements about overall service quality of restaurants based on their assessment of physical attributes. Mattila (2001) concluded that atmosphere is a crucial influencing factor of customers dining experiences. Bitner (1992) proposed that the ambience of restaurants is one kind of nonverbal communication with consumers. Moreover, Bitner (1992) asserted that the positive effect of a good tangible service environment could compensate for the negative feelings generated by a poor intangible service. Kaplan and Kaplan (1989) and Bitner (1992) pointed out that the ambience elicits cognitive responses such as perceived service quality, which affect customers' assessment of the products and personnel in that place. Soriano (2002) found that the attention in terms of the relationship between detailed ambience attributes (i.e. hygienic and harmonious eating environment, suitable layout arrangement) and perceived service quality has been developing in the past two decades. Wakefield and Blodgett (1999) investigated the function of 
cleanliness in leisure service settings. Ryu and Jang (2007) found that there was high correlation between spatial layouts (i.e. equipments, furnishings) and perceived service quality in an upscale restaurant. Newman (2007) proposed the effect of spatial density on the evaluations of service quality. In addition, Stokols (1972) claimed that highly dense setting conditions could lead to poor perceptions of over crowing by patrons, which in turn make them feel that their personal space is limited and threatened. A similar result has been reported by Yildirim and Akalin-Baskaya (2007). They tested 465 patrons in a single restaurant and concluded that patrons perceived better service quality when the restaurant is less crowded. In empirical studies, substantial researchers suggested that ambience quality is very important in indicating customer satisfaction (Clark and Wood, 1999; Namkung and Jang, 2008; Kim and Moon, 2009). Consistent with these findings, we develop our third hypothesis:

\section{H3. Ambience quality positively and significantly influences customer satisfaction.}

\subsubsection{Price}

Besides food, service and ambience attributes, price has been identified as another attribute that affects customers perceptions of restaurants performance largely. Scholars have claimed that the price could be as a surrogate for quality (Olson, 1977). A related criterion is price fairness. It refers to the extent to which patrons evaluate price is reasonable, acceptable and just (Bolton et al., 2003). As the booming restaurant market supplies a variety of selections for patrons, and as dining out becomes an integral part of the daily lifestyle, consumers tend to be more experienced and have the motivation to seek a better value for their consumption (Klara, 2001). Accordingly, high-quality of food and service are not enough for customers to evaluate the restaurants performance. In their mind, the value of their money is demanded (Teboul, 1991). Price also plays a key role in indicating customer satisfaction due to its ability of attracting or repelling customers (Fornell et al., 1996). Our fourth hypothesis is consistent with this literature:

\section{H4. Price perception positively and significantly influences customer satisfaction.}

\subsubsection{Overall customer satisfaction}

Intentions of future purchases by consumers are often shaped by their previous purchasing experiences (Colgate and Lang, 2001; Iglesias and Guillen, 2004). Hansen et al (2004) proposed that instead of telling their compliments to the firm, the satisfied consumers are more likely to share their satisfied experiences with others. In the restaurant context, customer satisfaction could be explained as the motivation of patrons to revisit a specific restaurant and to recommend it to their family, friends and others in the future. Thus, in this study, customer satisfaction is measured in terms of the customers' intention to revisit the restaurant again and their willingness to recommend the restaurant to friends (Colgate and Lang, 2001; Hansen et al., 2004; Iglesias and Guillen, 2004). 


\subsubsection{Customer characteristics as moderators}

It has generally been observed that the relationships between service quality attributes and overall satisfaction could be influenced by certain characteristics of customers. The theory of consumer behaviour (Holbrook, 1995) predicts that different personal characteristics of customers influence customers purchasing behavior in any shopping environment. This has also been verified empirically. For example, factors such as gender, education and income have been found to affect purchase behaviour of customers (Slama and Tashchian, 1985). In the context of restaurants, Chow et al. (2007) have found that gender, age and income level of consumers affected their repeat purchase intention. In contrast, some other researchers studied such moderating influences but did not find satisfactory evidence. For example, Soriano (2002) has investigated customer satisfaction in Spanish restaurants, and concluded that satisfaction levels did not significantly vary between male and female customers. Namkung and Jang (2008) observed four restaurants (two are American restaurants, others are Korean restaurant and Japanese restaurant), and claimed that no significant differences existed between satisfied and non-satisfied customers in terms of age and annual household income. Thus, the moderating influence of customer characteristics on service quality is not a conclusive one. In this study, we provide another test of customer characteristics by stating our final hypothesis.

H5. Customer characteristics (age, gender and income level) significantly influence the relationships between service quality attributes and customer satisfaction. 
All posited hypotheses in this study are sketched in Figure 1.

Figure 1: Hypothesized research model for the restaurant

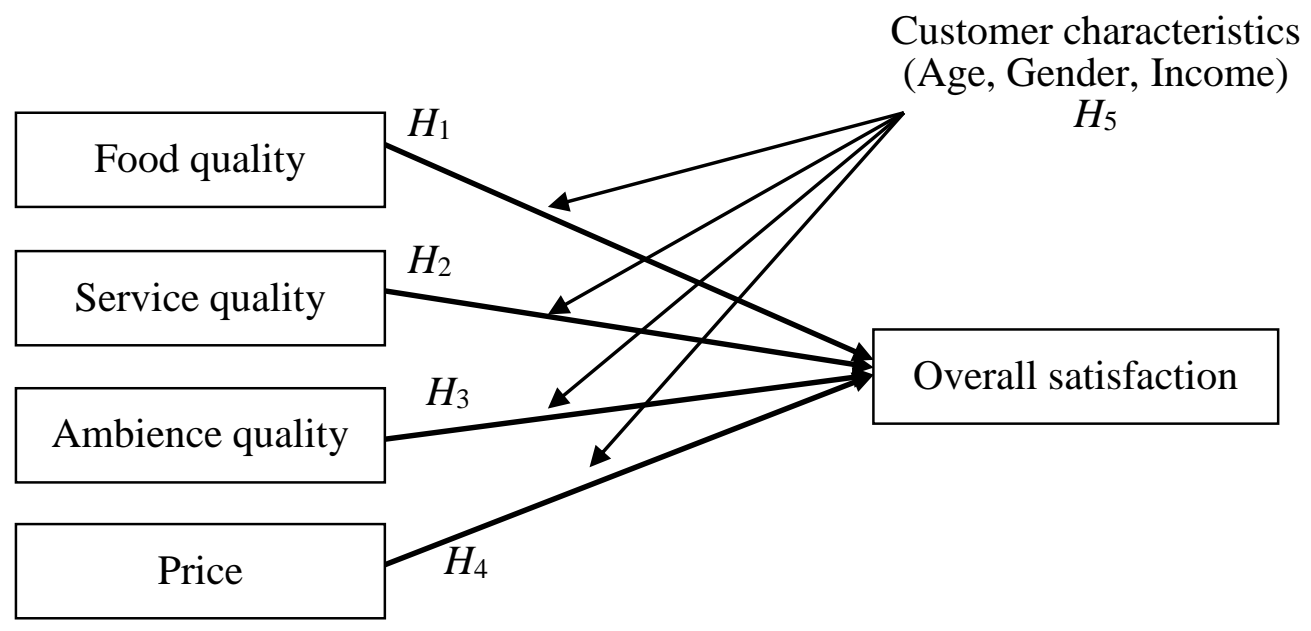




\section{Research methodology - Questionnaire design and data collection}

A self-administered questionnaire was designed in order to gather primary data. A review of academic studies and commercial research with respect to restaurants overall service quality, and the predictors of customer satisfaction were applied as support. The final questionnaire comprised 33 items, and it was divided into 4 parts. Table 1 provides the 33 items along with the literature sources.

Table 1: Literature sources for the questions used in the questionnaire

\begin{tabular}{|c|c|}
\hline Attribute & Source \\
\hline \multicolumn{2}{|l|}{ Food-related attributes (11 items) } \\
\hline Temperature, Accessibility, & Soriano, 2002; Johns and Pine, 2002; Warde and Martens, \\
\hline Presentation Freshness & 2000; Gustafsson, 2004; Wansink, 2005; Hansen, 2005 \\
\hline Safety & Sulek and Hensley, 2004 \\
\hline Health (low calorie dishes and & Schifferstein and Oude Ophuis, 1998; Roininen et al., 1999; \\
\hline vegetarian options) & Roininen et al., 2001 \\
\hline \multirow[t]{2}{*}{ Food innovation and uniqueness } & Auty, 1992; Kivela, 1997; Bowie and Chang, 2005; Lin and \\
\hline & Mattila, 2006 \\
\hline \multirow[t]{2}{*}{ Authenticity and localisation } & Ebster and Guist, 2004; Wood and Munoz, 2006; Fine, 1992; \\
\hline & Lee et al., 2004 \\
\hline \multicolumn{2}{|l|}{ Service-related attributes (12 items) } \\
\hline Replenishment of dishes Plates & Pugh, 2001 \\
\hline \multicolumn{2}{|l|}{ withdrawal, Error-free billing } \\
\hline Reservation honoured, reservation via & Lee and Hing, 1995 \\
\hline Language Communication & Law et al., 2008 \\
\hline Dishes' information labelled, & Brian et al., 2005 \\
\hline Operating time, Location, Individual & Sun, 1995; Soriano, 2002; Tzeng et al., 2002 \\
\hline \multicolumn{2}{|l|}{ Ambience-related attributes (4 items) } \\
\hline Cleanliness & Soriano, 2002; Wakefield and Blodgett, 1996 \\
\hline Queue near meals & Davis and Heineke, 1994; Baker and Cameron, 1996 \\
\hline Waiting room availability & Davis, 1991; Rhonda and Joanne, 2007; Law et al., 2004; \\
\hline \multirow[t]{2}{*}{ Seating arrangement } & Soriano, 2002; Ryu and Jang, 2007; Newman, 2007; Stokols, \\
\hline & 1972; Yildirim and Akalin-Baskaya, 2007 \\
\hline
\end{tabular}

Price-related attributes ( 3 items) 
Worthy price, Discount price for students
Bolton et al., 2003; Klara, 2001; Kahneman et al., 2002; Kims and Wirtz, 2002; Teboul, 1991

Satisfaction-related attributes (3

Customer satisfaction, Return again,

Colgate and Lang, 2001; Iglesias and Guillen, 2004; Hansen

Recommend to friends et al., 2005

In the introductory part of the questionnaire, the purpose of this survey was asked. In the second part, the questionnaire required respondents to indicate their personal information, consisting of gender, age and monthly income. These are the most generally applied demographic attributes in the operations service industry research (Weber, 2005).

In the content page, some instructions about how to answer the questions were first provided. Then respondents were asked to measure overall service quality provided by the restaurant through thirty questions listed in section one. This formed the third part of the questionnaire. In section two (which formed the fourth part of the questionnaire), respondents were asked to evaluate their overall satisfaction with the restaurant.

This study has used performance-only measurement instead of traditional SERVQUAL instrument, which is in line with some recent observations (e.g., Roses et al., 2009). A 7-point Likerttype scale was utilized, which ranged from $1=$ strongly disagree to $7=$ strongly agree. Respondents were asked to rate the score for all attributes. The questionnaire was designed in English and Chinese. Each attribute was first stated in English and was then translated into corresponding Chinese. Taking into consideration that a majority of patrons of the restaurant are Chinese, the Chinese-stated part of the questionnaire can help them better understand. In this sense, more respondents can take part in this survey. Thereby, the applicability and reliability of the analysis results would be improved.

In order to ensure the validity of content, questionnaire was pilot-tested by 9 Chinese and 16 English respondents. After accounting for their comments, a large-scale survey was performed in the next three weeks. Random sampling was used for questionnaire survey. The respondents who were waiting for check out were randomly selected. One of the authors read the statements for respondents and marked in the questionnaire on behalf of the respondents. The majority of questionnaires were selected through this way. And a minor of questionnaires were filled out by respondents in person. For the sake of ensuring the variety of respondents, only the leader of each group was chosen, and without discrimination in terms of gender, age, or monthly income level when selected. Respondents participated in the survey on a voluntary basis. A total of 204 completed questionnaires were received, all of them were used in the data analysis. 


\section{Data analysis and results}

A series of different statistical analysis were performed to analyse the questionnaire data. The software, SPSS 16.0, was employed for the purpose.

\subsection{Demographic and dining out profiles}

Table 2 reports the total of 204 respondents demographic and dining out profiles in detail. Among respondents, $45.1 \%$ were male, and the rest were female. The majority age of respondents ranged from 31-40. The largest proportion of respondents monthly income ranged from $£ 2,000$ to $£ 3,000$. The major respondents dine out one or two times weekly $(53.4 \%)$.

Table 2: Demographic and dining out profiles of respondents ${ }^{\mathrm{a}}$

\begin{tabular}{|c|c|c|c|}
\hline Characteristic & Category & Number & Percentage (\%) \\
\hline \multirow[t]{2}{*}{ Gender } & Male & 92 & 45.1 \\
\hline & Female & 112 & 54.9 \\
\hline \multirow[t]{6}{*}{ Age } & 20 or below & 1 & .5 \\
\hline & 21-30 & 51 & 25.0 \\
\hline & $31-40$ & 59 & 28.9 \\
\hline & $41-50$ & 43 & 21.1 \\
\hline & $51-60$ & 21 & 10.3 \\
\hline & 61 or above & 29 & 14.2 \\
\hline \multirow[t]{5}{*}{ Monthly Income } & Less than $£ 1,000$ & 24 & 11.8 \\
\hline & $£ 1,000-£ 2,000$ & 11 & 5.4 \\
\hline & $£ 2,000-£ 3,000$ & 62 & 30.4 \\
\hline & $£ 3,000-£ 4,000$ & 48 & 23.5 \\
\hline & $£ 4,000-£ 5,000$ & 59 & 28.9 \\
\hline \multirow[t]{4}{*}{ Group visiting } & Alone & 17 & 8.3 \\
\hline & Family & 65 & 31.9 \\
\hline & Friends & 96 & 47.1 \\
\hline & Business colleagues & 26 & 12.7 \\
\hline \multirow[t]{4}{*}{ Frequency of dining out } & Almost never & 1 & .5 \\
\hline & One or two times & 109 & 53.4 \\
\hline & Three or four times & 80 & 39.2 \\
\hline & More than five times & 14 & 6.9 \\
\hline \multirow[t]{3}{*}{ Frequency of visit } & Once & 187 & 91.7 \\
\hline & Two times & 15 & 7.4 \\
\hline & Three times & 2 & 1.0 \\
\hline
\end{tabular}

\subsection{Descriptive statistics}

The descriptive statistics is presented in Table 3. It can be seen from this table that the majority of items were rated highly by patrons, varied from score 4 to 7 . The mean scores were around 5 . 
These values imply the fact that patrons evaluate overall service quality of the restaurant at a rather high level, and they are generally with the service provided by the restaurant. On the contrary, customized service (measured in terms of pay attention to customers specific requirements) (ranging from score 2 to 5) and ambience-related attributes (ranging from score 3 to 7) showed comparatively lower evaluations.

Table 3: Descriptive statistics of questionnaire items

\begin{tabular}{llccccc}
\hline No. & Item & $N$ & Min & Max & Mean & S.D. \\
\hline 1 & Food temperature & 204 & 4 & 7 & 5.49 & .803 \\
2 & Food accessibility & 204 & 4 & 7 & 5.35 & .900 \\
3 & Food presentation & 204 & 4 & 7 & 5.50 & .785 \\
4 & Food freshness & 204 & 4 & 7 & 5.54 & .821 \\
5 & Food safety & 204 & 4 & 7 & 5.57 & .888 \\
6 & Low-calorie dishes & 204 & 4 & 7 & 5.63 & .966 \\
7 & Vegetarian dishes & 204 & 4 & 7 & 5.76 & .908 \\
8 & Food innovation & 204 & 4 & 7 & 5.57 & .842 \\
9 & Food uniqueness & 204 & 4 & 7 & 5.55 & .820 \\
10 & Food variety & 204 & 4 & 7 & 5.60 & .868 \\
11 & Food authenticity and localization & 204 & 4 & 7 & 5.80 & .803 \\
12 & Replenishment of dishes & 204 & 4 & 7 & 5.16 & .853 \\
13 & Plates withdrawal & 204 & 4 & 7 & 5.08 & .867 \\
14 & Reservation honoured & 204 & 4 & 7 & 5.22 & .896 \\
15 & Error-free billing & 204 & 4 & 7 & 5.17 & .874 \\
16 & Language communication & 204 & 4 & 7 & 5.16 & .898 \\
17 & Dishes information labelled & 204 & 4 & 7 & 5.26 & .893 \\
18 & Separating and signing buffet sections & 204 & 4 & 7 & 5.16 & .891 \\
19 & Operating time & 204 & 4 & 7 & 5.51 & .890 \\
20 & Location & 204 & 4 & 7 & 5.46 & .856 \\
21 & Website information & 204 & 4 & 7 & 5.38 & .910 \\
22 & Website reservation & 204 & 4 & 7 & 5.52 & .739 \\
23 & Customized service & 204 & 2 & 5 & 3.49 & .857 \\
24 & Cleanliness & 204 & 3 & 7 & 5.02 & .893 \\
25 & Queue near meals & 204 & 3 & 7 & 4.74 & 1.002 \\
26 & Waiting room availability & 204 & 3 & 7 & 4.65 & .877 \\
27 & Seating arrangement & 204 & 3 & 7 & 4.82 & .909 \\
28 & Worthy price & 204 & 4 & 7 & 5.47 & .833 \\
29 & Discount price for students & 204 & 4 & 7 & 5.65 & .900 \\
30 & Differed price for different time periods & 204 & 4 & 7 & 5.80 & .809 \\
31 & Customer satisfaction & 4 & 7 & 5.61 & .790 \\
32 & Return again & 7 & 5.56 & .866 \\
& & & & &
\end{tabular}




\subsection{Factor analysis}

We first employed exploratory factor analysis to analyse the data. Factor analysis is able to narrow down the substantial numbers of attributes and group them into factors. Principal component analysis with a Varimax Rotation method was utilized and factor loadings above 0.4 without cross loaded was considered (van Dyke et al., 1999). A confirmatory factor analysis was subsequently undertaken and the results are available in Table 4. Eighteen items loaded into four latent factors with an eigenvalue greater than 1 . The reliability of the latent factors was tested using Cronbach's Alpha. It can be seen from Table 4 that the Cronbachs Alpha of four factors (ranged from 0.649 to 0.866 ) are higher than the acceptable value 0.60 (Nunnally, 1978).

Table 4: Results of confirmatory factor analysis of questionnaire data

\begin{tabular}{lccc}
\hline & Cronbachs Alpha & \% of Variance & KMO Statistics \\
\hline Food Factor (4 items) & .649 & 49.008 & .702 \\
- Food presentation & & & \\
-Food safety & & & \\
-Vegetarian dishes & & & .870 \\
-Authenticity and localization & & & \\
\hline Service Factor (7 items) & .834 & & \\
-Plates withdrawal & & & \\
-Language communication & & & \\
-Dishes information labelled & & & \\
-Operating time & & & \\
-Location & & & \\
-Website information & & & \\
-Website reservation & & & \\
\hline $\begin{array}{l}\text { Ambience Factor (4 items) } \\
\text {-Cleanliness }\end{array}$ & .866 & \\
-Queue near meals \\
-Waiting room availability \\
-Seating arrangement
\end{tabular}

Table 5 reports the correlation between factors - food, service, ambience, price and overall satisfaction. Many of the correlations reported in the table are significant.

Table 5: Correlation matrix of questionnaire data

Food Factor Service Factor Ambience Factor Price Factor




\begin{tabular}{lcccc} 
Service Factor & -.096 & & \\
Ambience Factor & -.074 & $-.228^{* *}$ & \\
Price Factor & -.010 & $-.409^{* *}$ & $-.161^{*}$ & \\
Overall Satisfaction & $.256^{* *}$ & .109 & $-.268^{* *}$ & $.253^{* *}$ \\
\hline **. Correlation is significant at the 0.01 level (2-tailed). & \\
*. Correlation is significant at the 0.05 level (2-tailed). \\
\hline
\end{tabular}

\subsection{Multiple-Regression analysis}

We have used multiple-regression analysis to test our hypotheses. Accordingly, the structure of multiple-regression can be expressed as following: overall satisfaction $=\mathrm{f}$ (food factor, service factor, ambience factor, price factor) (Hair et al., 2006). In this regression equation, four factors are the independent variables and overall satisfaction is the dependent variable. The results of regression analysis are displayed in Table 6.

Table 6: Regression results ${ }^{\mathrm{a}}$

\begin{tabular}{|c|c|c|c|c|}
\hline & $\begin{array}{l}\text { Standardized } \\
\text { Coefficients } \\
\text { Beta }\end{array}$ & $R^{2}$ & $\begin{array}{c}\text { Adjusted } \\
R^{2}\end{array}$ & $F$ \\
\hline Food Factor & $.300 * *$ & .214 & .199 & $13.569 * *$ \\
\hline Service Factor & $.150 *$ & & & \\
\hline Ambience Factor & $-.204 * *$ & & & \\
\hline Price Factor & $.248 * *$ & & & \\
\hline \multicolumn{5}{|c|}{$\begin{array}{l}\text { a. Dependent Variable: Overall satisfaction } \\
* * \text {. Correlation is significant at the } 0.01 \text { level (2-tailed). } \\
* \text {. Correlation is significant at the } 0.05 \text { level (2-tailed). }\end{array}$} \\
\hline
\end{tabular}

We checked for the presence of multi-collinearity and heteroskedasticity that could potentially violate the assumptions of Ordinary Least Squares regression (Hair et al., 2006). Values of variable inflation factors were all below 10 indicating that multi-collinearity was not a problem. The graph of residuals showed no specific pattern, indicating no problems with heteroskedasticity. The results in Table 6 show that the four factors contributed significantly $(F=13.569, p<0.01)$ and explained $19.9 \%$ of the variance in overall satisfaction (Adjusted $R^{2}=0.199$ ).

We can use the results of regression in Table 6 to verify our first four hypotheses. This testing is described in Table 7. Thus, all the four factors significantly affect overall satisfaction. At the level of $p=0.000$, food factor presents positive and the closest relationship with overall satisfaction. It means that food factor is the most significant indicator of overall satisfaction. Hence, hypothesis 1 which posits positive and significant relationship between food factor and overall satisfaction is supported. Similarly, price factor shows positive and significant relationship with overall satisfaction 
as well $(p=0.001)$. Therefore, hypothesis 4 which infers positive and significant relationship between price factor and overall satisfaction is supported. Though ambience factor significantly affects overall satisfaction ( $p=0.003$ ), it represents negative relationship with overall satisfaction. Thus, hypothesis 3 which investigates a positive and significant relationship between ambience factor and overall satisfaction is only partially supported. This negative relationship implies - although customers measure ambience quality of the restaurant is low, they still evaluate a high level of satisfaction with respect to the restaurants overall service quality. The manager should pay more attention in ambience quality, since it has a significant effect on overall satisfaction.

Table 7: Results of hypothesis testing

\begin{tabular}{lccc}
\hline Hypothesis & \multicolumn{2}{c}{ Relationship with overall satisfaction } & Testing result \\
\hline 1. Food & Positive & $\begin{array}{c}\text { Highest Significance } \\
(p=.000)\end{array}$ & Supported \\
2. Service & Positive & $\begin{array}{c}\text { Fourth Significance } \\
(p=.043)\end{array}$ & Supported \\
3. Ambience & Negative & $\begin{array}{c}\text { Third Significance } \\
(p=.003)\end{array}$ & Partially Supported \\
4. Price & Positive & $\begin{array}{c}\text { Second Significance } \\
(p=.001)\end{array}$ & Supported \\
\hline
\end{tabular}

Finally, compared with other three factors, service factor has a lower level $(p=0.043)$ of significance in explaining the overall satisfaction. However, it still has a significant and positive effect on overall satisfaction. Accordingly, hypothesis 2 which posits the positive and significant relationship between service factor and overall satisfaction is supported.

Thus the food factor has the most significant impact on overall satisfaction, followed by price, ambience and service respectively.

\subsubsection{Multi-group Analysis}

To test the moderating impacts of gender, age and monthly income, we have divided our sample into multiple groups in terms of these variables and performed multiple regression analysis for each group. This way of multigroup regression analysis is consistent with the literature (e.g., Gilbert et al., 2014). Results are shown in Table 8.

Table 8: Regression results of multi-group analysis

\begin{tabular}{|c|c|c|c|c|c|c|c|c|}
\hline Variable $^{a}$ & $N$ & $\begin{array}{c}\text { Food } \\
\text { Factor }\end{array}$ & $\begin{array}{l}\text { Service } \\
\text { Factor }\end{array}$ & $\begin{array}{c}\text { Ambience } \\
\text { Factor }\end{array}$ & $\begin{array}{c}\text { Price } \\
\text { Factor }\end{array}$ & $R^{2}$ & $\begin{array}{c}\text { Adjusted } \\
R^{2}\end{array}$ & $F$ \\
\hline \multicolumn{9}{|l|}{ Gender } \\
\hline Male & 92 & $.257 *$ & $.260 * *$ & $-.258 * *$ & $.242 * *$ & .296 & .264 & $9.149 * *$ \\
\hline Female & 112 & $.281 * *$ & $.285^{*}$ & .004 & $.433 * *$ & .197 & .167 & $6.582 * *$ \\
\hline \multicolumn{9}{|l|}{ Age } \\
\hline $21-30$ & 51 & $.103^{* * *}$ & $.128 * *$ & .129 & .136 & .416 & .365 & $8.193^{* *}$ \\
\hline $31-40$ & 59 & .148 & .326 & -.047 & .229 & .131 & .066 & 2.032 \\
\hline
\end{tabular}




\begin{tabular}{|c|c|c|c|c|c|c|c|c|}
\hline $41-50$ & 43 & .344 & .054 & -.146 & .252 & .189 & .104 & 2.220 \\
\hline 61 or above & 29 & .179 & .100 & -.092 & $.726 * *$ & .386 & .284 & $3.780 *$ \\
\hline \multicolumn{9}{|l|}{ Monthly Income } \\
\hline$£ 2,000-£ 3,000$ & 62 & .004 & .276 & -.005 & $.415^{* *}$ & .183 & 0.147 & $3.186^{*}$ \\
\hline$£ 3,000-£ 4,000$ & 48 & $.481 * *$ & $.426 * *$ & -.203 & $.460 * *$ & .471 & 0.424 & $9.581 * *$ \\
\hline$£ 4,000$ and above & 59 & $.347 * *$ & -.0 .98 & -.151 & .162 & .256 & 0.246 & $4.644 * *$ \\
\hline
\end{tabular}

a. Dependent Variable: Overall satisfaction

**. Correlation is significant at the 0.01 level (2-tailed).

*. Correlation is significant at the 0.05 level (2-tailed).

Gender seems to moderate the importance of food factor, service factor and ambience factor on overall satisfaction (Table 8). The most notable difference is on the relationship between ambience factor and overall satisfaction. For males, ambience is negatively but significantly related to satisfaction while the factor does not have significant impact for the satisfaction of female patrons. This result is consistent with those of Chow et al (2007), who asserted that male patrons have commonly higher expectations of service quality, and are especially concerned with physical environment of the restaurant.

The results of Table 8 also show that the influence of the four factors on satisfaction significantly differed for patrons of different age groups. Thus a strong moderating impact of age is predicted in our study. In comparison to other age groups, customers aged 61 or above consider price as a significant factor influencing satisfaction $(p=0.003)$. It makes sense that the majority of people in this age are retired with limited incomes, which in turn lead to the price sensitivity of this group. Similarly, monthly income of patrons has a significant moderating impact. Due to lower incomes, groups with monthly income from $£ 2,000$ to $£ 3,000$ ( $p=0.001$ ) and from $£ 3,000$ to $£ 4,000$ ( $p=0.008$ ) consider price factor as significant in deciding their levels of satisfaction. Not unexpectedly, for the group with higher monthly income (above $£ 4,000$ ), price is not regarded as a significant factor $(p=0.265)$. Instead, they are more likely to be concerned with food quality of the restaurant offered $(p=0.009)$.

In summary, the results shown in Table 8 support our hypotheses on the moderating roles of gender, age, and monthly income.

\section{Discussion, managerial implications and conclusions}

Results of our multiple-regression analysis in Table 7 have shown that food factor is viewed as the most important determinant of customer satisfaction, followed by in order, price factor, ambience factor, service factor in the restaurant. Among them, food, price and service factor present significant and positive relationship with customer satisfaction. Ambience factor represents the vital, however, negative correlation with customer satisfaction. We have also found, from the results of Table 8 , that 
gender, age and monthly income of patrons significantly moderate the relationship between the four factors (food, service, ambience and service) and overall satisfaction.

\subsection{Effects of the four factors on customer satisfaction on service quality}

Our results show that food quality has a very high influence on customers' perception of overall satisfaction from restaurants. Food, as an essential component of dining experience, presents positive and the closest relationship with customer satisfaction. This opinion is supported by a number of previous studies (Law et al., 2004; Chow et al., 2007). It is no doubt that food has, and would continue to have the paramount effect on customer satisfaction. Taking into consideration the demands of more food-savvy and experienced patrons, restaurants should not only provide tasty with appealing presentation food that outperform competitors, but offer also safe and healthy food in order to response to customers' health requirements.

In contrast, service factor is found to have a significant influence on customer satisfaction, though the level of significance is lower compared to that of the other three factors. This conclusion is somewhat supported by an investigation undertaken by Johns and Howard (1998). They investigated expectations and perceptions of 100 customers on service quality in two pizza restaurants and concluded that service encounter is viewed as a not significant element compared with food, drink, environment, and atmosphere. It might be considered as a unique feature in fast-food restaurant industry, in which interaction between customer and server is less than full-service restaurants.

Surprisingly, this study has found that ambience factor negatively affects customer satisfaction. This result may be explained from a psychology perspective. According to Tse et al (2002), when consumers perceive a restaurant has very crowded environment, they would attribute this high level of crowdedness to high food quality, good reputation, and low price which motivate people to visit the restaurant. On the contrary, if the restaurants environment is so quiet, the consumer would link the quietness with low food quality, poor reputation and high price. It seems to be a dilemma for restaurateurs. In this sense, how to balance the layout arrangement and the level of crowdedness is a challenge that must be faced by restaurant operators.

For a majority of patrons, the comparatively inexpensive food options of the restaurant have provided an incentive towards their satisfaction. This result is generally supported in the literature. Even some studies that found price to be insignificant did not argue against this factor. For example, although Qin and Prybutok (2009) and Pollack (2008) have concluded that price is not a significant indicator of customer satisfaction in their empirical research, they have believed that price maybe relatively homogenous among the restaurants in their studies thus exhibiting insignificant variation relative to the other factors.

\subsection{Moderating influence of customer characteristics}

Using regression analysis, this study has found that all the three moderating variables (viz. age, gender and monthly income) had a significant moderating role on the relationships between service 
quality factors and overall satisfaction. By doing so, it echoes some findings of previous studies (e.g., Chow et al., 2007) but negates findings of Soriano (2002). Male customers expected better service quality for the price they pay. This result is in line with the findings of Chow et al (2007). People in the age of 21-30 provide higher importance for food and service factors. Older people have provided higher importance for the price attribute. These findings reflect the priority of each category of customers specifically on four factors, which can help managers to change their approach to improve overall satisfaction.

These findings have interesting implications for the managers of buffet restaurants. First, managers should spend efforts to improve all the four factors as all of them significantly influence satisfaction levels of customers. Price factor is important to both male and female customers. It is important for older customers (above 61 years of age) and to people in lower income groups ( $£ 2,000$ 3,000 and $£ 3,000-£ 4,000$ ). Hence, the perception of charging reasonable price is crucial. Younger people (21-30 years) and higher income customers ( $£ 3,000$ and above) give high importance to food. Service is important for younger customers and customers with middle income levels. The relatively lower importance of service may be because the study is done in a buffet restaurant rather than a fullservice restaurant. Overall, food and price seem to be important across more number of demographic characteristics, while ambience and service are important across fewer numbers of demographic characteristics. Managers should be provide facilities that reflects this relative importance.

\subsection{Conclusions}

Service sector failures are partly due to the lack of strategic orientation in measuring overall service quality and focusing on customer satisfaction. Identifying critical attributes and associated factors among diverse candidates are essential for maximizing customer satisfaction in sector sectors such as restaurants, hotels and hospitals. The results of this study can be useful to prioritize factors and determine which aspects should be most addressed in restaurants. This could help managers allocate their limited resources effectively and help achieve customer satisfaction in the most economical way.

This study concludes that all the four factors (food, service, ambience and price) are significant determinants of customer satisfaction. All except the ambience factor have positive impacts. Gender, age and monthly income of respondents have significant moderating impacts on these relationships. This research can be taken as a basis for identifying important factors of service quality to satisfy customers in the light of developing service operations quality to sustain ever growing competition. Our research approach can be extended for other service sectors such as hospitals and educational institutions.

The results of this study are not without limitations. One main limitation is that the data was collected in only one restaurant. More comprehensive analysis is possible when similar data is collected for multiple restaurants. Another limitation is that this study did not consider brand element and environment factors in customer satisfaction. It did not consider a particular brand and chain of 
restaurants but focused on a family-owned, single shop restaurant. Future research is needed to examine whether brand attribute plays an important role in affecting customer satisfaction.

\section{References}

Adam, E.E. and Swamidass, P.M. (1989), “Assessing operations management from a strategic perspective", Journal of Management, Vol. 15 No. 2, pp. 181-203.

Berry, L.L., Carbone, L.P. and Haeckel, S.H. (2002), "Managing the total customer experience", Sloan Management Review, Vol. 43 No.3, pp. 85-9.

Bitner, M.J. (1992), "Servicescape: the impact of physical surrounding on customers and employees", Journal of Marketing, Vol. 56 No.2, pp.57-67.

Bolton, L.E., Warlop, L. and Alba, J.W. (2003), "Consumer perceptions of price (Un) fairness", Journal of Consumer Research, Vol. 29 No. 4, pp.474-92.

Cao, Y. and Kim, K. (2015), "How do customers perceive service quality in differently structured fast food restaurants?", Journal of Hospitality Marketing \& Management, Vol. 24 No. 1, pp. 99-117.

Chow I.H.S., Lau, V.P., Lo, T.W-c., Sha, Z. and Yun, H. (2007), "Service quality in restaurant operations in China: Decision- and experience-oriented perspectives", Hospitality Management, Vol. 26, pp.698-710.

Clark, M.A. and Wood, R.C. (1999), "Consumer loyalty in the restaurant industry: A preliminary exploration of the issues”, British Food Journal, Vol. 101 No. 4, pp.317-26.

Colgate, M. and Lang, B. (2001), "Switching barriers in consumer markets: an investigation of the financial services industry", Journal of Consumer Marketing, Vol.18 No. 4, pp. 332-47. Fitzsimmons J. A. and Fitzsimmons, M. J. (2008), "Service Management: Operations, Strategy, Information Technology", 6th Edition, McGraw-Hill, New York

Fornell, C., Johnson, M.D., Anderson, E.W., Cha, J. and Bryant, B.E. (1996), "The American customer satisfaction index: nature, purpose, and findings", Journal of Marketing, Vol. 60 No. 4, pp.7-18.

Gilbert, G. R., Myrtle, R. C., \& Sohi, R. S. (2015), "Relational Behavior of Leaders A Comparison by Vocational Context”, Journal of Leadership \& Organizational Studies, Vol. 22 No. 2, pp.149-160.

Hair, J.F., Black, W.C., Babin, B.J., Anderson, R.E. and Tatham, R.L. (2006), "Multivariate Data Analysis", $6^{\text {th }}$ edition Prentice-Hall, New Jersey.

Hansen, K.V., Jensen, Ø. and Gustafsson, I.-B. (2004), "Payment- an undervalued part of the meal experience?", Food Service Technology, Vol.4, pp.85-91.

Holbrook, M.B. (1995), "Consumer Research: Introspective Essays on the Study of Consumption", Sage Publications, London. 
Iglesias M.P. and Guillen M.F.Y. (2004), "Perceived quality and price: their impact on the satisfaction of restaurant customers", International Journal of Contemporary Hospitality Management, Vol.16, No. 6, pp. 373-79.

Johns, N. and Howard, A. (1998), "Customer expectations versus perceptions of service performance in the foodservice industry", International Journal of Service Industry Management, Vol. 9 No. 3, pp. 248-56.

Johns, N. and Pine, R. (2002), “Consumer behavior in the food service industry: a review”, International Journal of Hospitality Management, Vol. 21, pp.119-34.

Kaplan, R. and Kaplan, S. (1989), “The Experience of Nature: A Psychological Perspective”, Cambridge University Press, New York.

Kim, W.G. and Moon, Y.J. (2009), "Customers cognitive, emotional, and actionable response to the servicescape: A test of the moderating effect of the restaurant type", International Journal of Hospitality Management, Vol. 28, pp. 144-56.

Kivela, J. (1997), "Restaurant marketing: selection and segmentation in Hong Kong", International Journal of Contemporary Hospitality Management, Vol. 9 No.3, pp. 116-23.

Klara, R. (2001), Please please me, Restaurant Business, 100(4), 22.

Law, A.K.Y., Hui, Y.V. and Zhao, X. (2004), "Modeling repurchase frequency and customer satisfaction for fat food outlets", International Journal of Quality and Reliability Management, Vol. 21 No. 5, pp. 545-63.

Law R., To, T. and Goh C., (2008), "How do Mainland Chinese travellers choose restaurants in Hong Kong? An exploratory study of individual visit scheme travellers and packaged travellers", International Journal of Hospitality Management, Vol. 27, pp. 346-354.

Lee, A.Y. (2009), "Engaging the consumer: The opposing forces of regulatory nonfit versus fit”, Journal of Consumer Psychology, Vol. 19 No.2, pp. 134-136.

Lee, Y.L. and Hing, N. (1995), "Measuring quality in restaurant operations: an application of the SERVQUAL instrument", International Journal of Hospitality Management, Vol. 14, pp. 293-310.

Lin, I.Y.H. and Mattila, A.S. (2006), "Understanding restaurant switching behavior from a cultural perspective", Journal of Hospitality and Tourism Research, Vol. 30 No. 1, pp. 3-15.

Lin, S-P. Yang, C-L, Chan, Y-h, Sheu, C. (2010). Refining Kano's 'quality attributessatisfaction' model: A moderated regression approach, International Journal of Production Economics, doi:10.1016/j.ijpe.2010.03.015

Mattila, A.S. (2001), "Emotional bonding and restaurant loyalty", The Cornell Hotel and Restaurant Administration Quarterly, Vol. 42, pp. 73-79.

Mintel International Group Ltd. (2008). Experts predict strong growth for UK restaurant market. The Food Magazine. 
Namkung Y. and Jang S.C.S., (2008), "Are highly satisfied restaurant customers really different? A quality perception perspective", International Journal of Contemporary Hospitality Management, Vol. 20 No.2, pp. 142-55.

Newman, A.J. (2007), "Uncovering dimensionality in the servicescape: towards legibility", The Service Industries Journal, Vol. 27 No. 1, pp. 15-28.

Nunnally, J.L. (1978). Psychometric Theory $2^{\text {nd }}$ edition. MaGraw-Hill, New York.

Olson, J. C. (1977). Price as an Informational Cue: Effects in Product Evaluation, in A.G.

Parasuraman, A., Zeithaml, V.A. and Berry, L.L. (1988), "SERVQUAL: a multiple-item scale for measuring consumer perceptions of service quality", Journal of Retailing, Vol. 64 No. 1, pp. 12-40.

Pugh, S.D. (2001), "Service with a smile: emotional contagion in the service encounter", Academy of Management Journal, Vol. 44 No. 5, pp. 1018-27.

Qin, H., and Prybutok, V.R. (2009), "Service quality, customer satisfaction, and behavioral intentions in fast-food restaurants", International Journal of Quality and Service Sciences, Vol. 1 No. 1, pp.78-95.

Pollack, B.L. (2008), "The nature of the service quality and satisfaction relationship: Empirical evidence for the existence of satisfiers and dissatisfiers", Managing Service Quality, Vol. 18 No.6, pp. 537-58.

Ramanathan, R. and Karpuzcu, H. (2011), "Comparing Perceived and Expected Service using an AHP Model: An Application to Measure Service Quality of a Company engaged in Pharmaceutical Distribution", Opsearch: Indian Journal of Operational Research, Vol. 48 No. 2, pp.136-152.

Reichenbach, H. (1999), "International food safety and HACCP conference - opening speech", Food Control, Vol. 10, pp. 235-37.

Reuland, R., Coudrey, J., and Fagel, A. (1985), "Research in the field of hospitality", International Journal of Hospitality Management, Vol. 4 No. 4, pp. 141-46.

Robledo M.A. (2001), "Measuring and managing service quality: integrating customer experience", Managing Service Quality, Vol. 11, pp. 22-31.

Roses, L.K., Hoppen, N. and Henrique, J.L., (2009), “ Management of perceptions of information technology service quality", Journal of Business Research, Vol. 62 No.9, pp. 876-882.

Rust, R.T. and Oliver, R.L. (1994), Service quality: insights and managerial implications from the frontier, In R.T. Rust and R.L. Oliver (Eds.), Service quality: New directions in theory and practice, pp. 1-19, Thousand Oaks, CA: Sage Publication. 
Ryu, K. and Jang, S. (2007), "The effect of environmental perceptions on behavioral intentions through emotions: the case of upscale restaurant, Journal of Hospitality and Tourism Research, Vol. 31 No. 7, pp. 56-72.

Shubber (2015), Restaurant sector turnover up 39\% since 2010, FT.com, May 18, 2015, Available online: $\quad$ http://www.ft.com/cms/s/0/5524e324-fc7d-11e4-800d00144feabdc0.html\#axzz3hT1dUKJ4, accessed on 31July2015.

Slama E. M. and Taschian, A. (1985), "Selected Socioeconomic and Demographic Characteristics Associated with Purchasing Involvement”, Journal of Marketing, Vol 49, pp. $72-82$.

Soriano, D.R. (2002), "Customers expectations factors in restaurants: the situation in Spain", International Journal of Quality and Reliability Management, Vol. 19, pp.1055-68.

Stokols, D. (1972), "On the distinction between density and crowding, Psychological Review", Vol. 79, pp. 275-7.

Sulek, J.M. and Hensley, R.L. (2004), "The relative importance of food, atmosphere, and fairness of wait", Cornell Hotel and Restaurant Administration Quarterly, Vol. 45 No. 3, pp. 235-47.

Teboul, J. (1991), Managing Quality Dynamics, Prentice-Hall, London.

Tzeng, G.H., Teng, M.H., Chen, J.J. and Opricovis, S. (2002), "Multicriteria selection for a restaurant location in Taipei”, International Journal of Hospitality Management, Vol. 21 No.2, pp. 171-87.

Tse, A.C.B., Sin, L. and Yim, F. H.K. (2002), "How a crowded restaurant affects consumers attribution behaviour", Hospitality Management. Vol. 21, pp. 449-54.

Van Dyke, T.P., Prybutok, V.R. and Kappelman, L.A. (1999), "Cautions on the use of the SERVQUAL measures to assess the quality of information systems services", Decision Sciences, Vol. 30 No. 3, pp.877-91.

Wakefield, K.L., and Blodgett, J.G., (1999), "Customer response to intangible and tangible service factors", Psychology and Marketing, Vol. 16 No.1, pp. 51-68.

Wansink, B. (2005), Marketing nutrition: Soy, functional foods, biotechnology, and obesity, Champaign, IL: University of Illinois Press.

Wansink, B., Ittersum, K.V. and Painter, J.E. (2005), "How descriptive food names bias sensory perceptions in restaurants", Food Quality and Preference, pp. 393-400.

Weber, K. (2005), "Travellers perceptions of airline alliance benefits and performance", Journal of Travel Research, Vol. 43 No.3, pp. 257-65.

Wirtz, J., Tuzovic, S. and Ehret, M. (2015), "Global Business Services: Increasing Specialization and Integration of the World Economy as Drivers of Economic Growth", Journal of Service Management, Vol. 26 No. 4 (in press). 
Yildirim, K. and Akalin-Baskaya, A. (2007), "Perceived crowing in a café/restaurant with different seating densities", Building and Environment, pp. 3410-17.

Yildiz, S. and Yildiz, E. (2015), "Service Quality Evaluation of Restaurants Using The Ahp And Topsis Method", Journal of Social and Administrative Sciences, Vol. 2 No.2, pp. 53-61. 